\title{
Kinetic effect of different ground conditions on the sole of the claws of standing and walking dairy cows
}

\author{
B. Oehme, S. Grund, J. Munzel, and C. K. W. Mülling* \\ Institute of Veterinary Anatomy, Histology and Embryology, Faculty of Veterinary Medicine, Leipzig University, Germany 04103
}

\section{ABSTRACT}

For the first time, we analyzed the direct kinetic effects of concrete and rubber flooring on the soles of live dairy cows' claws while standing and walking. Ten adult dairy cows were equipped with foil-based pressure sensors (HoofSystem, Tekscan Inc., Boston, MA) under their left hind leg using a leather claw shoe. These sensors captured parameters of pressure distribution and vertical ground reaction forces while the cows walked on the 2 tested flooring types. The mean pressure was 15.1 to $21.1 \%$ lower on rubber flooring compared with concrete; mean pressure values ( \pm standard deviation) were $36.32 \pm 7.77 \mathrm{~N} / \mathrm{cm}^{2}$ for static measures and 57.33 $\pm 11.77 \mathrm{~N} / \mathrm{cm}^{2}$ for dynamic measures. We observed an even more obvious relief on rubber flooring in the maximum pressure loads, which were 30.1 to $32.7 \%$ lower on rubber flooring compared with concrete; mean pressure values ( \pm standard deviation) were $98.79 \pm$ $14.49 \mathrm{~N} / \mathrm{cm}^{2}$ for static measures and $150.45 \pm 20.87 \mathrm{~N} /$ $\mathrm{cm}^{2}$ for dynamic measures). The force-time curves of the dynamic measures essentially showed biphasic curve progression, with local peaks at 29 and $79 \%$ of the stance phase. However, we found considerable differences in curve progression between individuals and between the lateral and medial claws, which may be verified in further investigations with more animals. The study showed a noticeable reduction in mechanical load during standing and walking on rubber flooring compared with concrete.

Key words: dairy cow, pressure distribution, forcetime curve, rubber flooring, concrete

\section{INTRODUCTION}

Lameness is one of the most important problems in modern dairy husbandry (Winckler and Brill, 2004; Barker et al., 2010; Hilger and Passarge, 2018) and is

Received December 19, 2018.

Accepted July 10, 2019.

*Corresponding author: christoph.muelling@vetmed.uni-leipzig.de caused mainly by claw lesions (Mülling and Lischer, 2002), especially in the hind limbs (Knott et al., 2007). These lesions not only cause considerable animal welfare problems but also generate economic losses due to declines in milk yield and fertility (Bicalho et al., 2008; Cha et al., 2010; Liang et al., 2017).

Because keeping the cows on hard flooring such as concrete can lead to a high prevalence of lameness or claw lesions (Vokey et al., 2001), an increasing number of farmers install rubber flooring on walkways. The influence of soft flooring on animal welfare and claw health has been the focus of numerous investigations. Compared with concrete, soft flooring led to improved gait cycles and longer stride length (Rushen and de Passillé, 2006; Flower et al., 2007; Telezhenko et al., 2017), and therefore longer walking distances (Bendel, 2005; Platz et al., 2008). Furthermore, less slipping and more comfort, as well as improved estrous behavior, were observed when cows were kept on rubber flooring (Benz, 2002; Bendel, 2005; Platz et al., 2008). Some authors found better claw health on rubber flooring (Benz, 2002; Jungbluth et al., 2003; Eicher et al., 2013), but others found no improvement (Vokey et al., 2001; Samel, 2005; Boyle et al., 2007) and some found an increase in sole ulcers (Kremer et al., 2007; Fjeldaas et al., 2011).

For a better understanding of the influence of different flooring types on the development of claw lesions, pressure measurement can be used; indeed, it has already been used in previous studies (Telezhenko et al., 2008; Bergsten et al., 2015). However, because these studies used static pressure plates, no direct effect of different flooring characteristics on the sole of the claws was captured (Franck et al., 2006). So far, the sole of the claws has been analyzed using only claw specimen models (Franck and De Belie, 2006; Oehme et al., 2018) and finite elements models (Franck et al., 2008; Hinterhofer et al., 2009). The use of thin, pressure-sensitive sensor foils is favorable for analyzing the direct interaction between flooring and claw, but so far they have been used in dairy cows' claws only in ex vivo studies (De Belie and Rombaut, 2003; Franck et al., 2006; Oehme et al., 2018). 

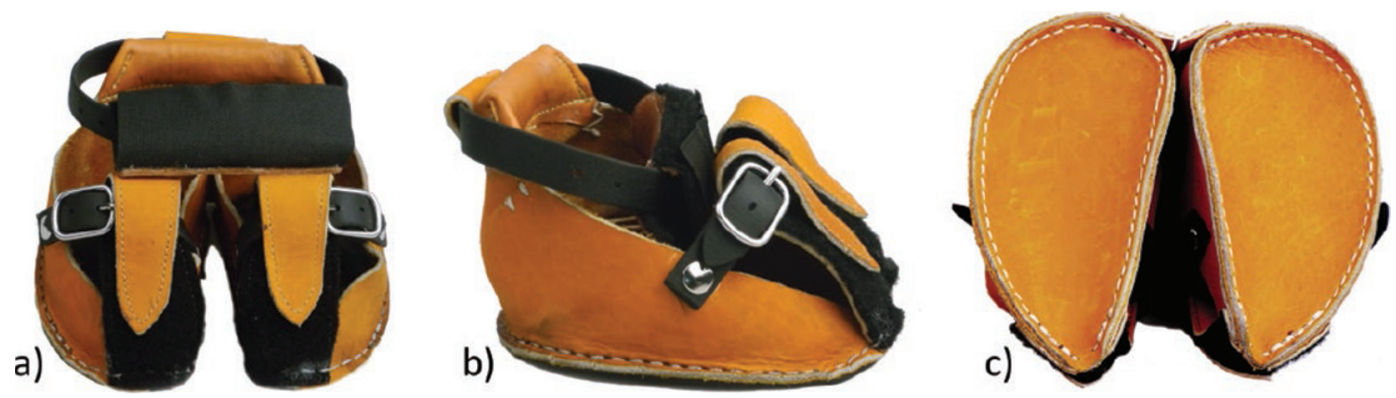

Figure 1. Leather claw shoe: (a) front view, (b) side view, and (c) bottom view.

The aim of this study was to apply a foil sensor-based pressure measurement system under the claws of live dairy cows while they were standing and walking to analyze the kinetic effect of concrete and rubber flooring on the sole of the claws.

\section{MATERIALS AND METHODS}

\section{Animals}

Ten adult Holstein-Friesian dairy cows (mean age 4.5 $\pm 0.6 \mathrm{yr}$ ) were selected for the study (ethical approval: TVV44/15, Landesdirektion Sachsen, Germany). They were part of the dairy herd of the Oberholz Farm for Teaching and Research (Faculty of Veterinary Medicine, Leipzig University) and were housed in a freestall barn with mastic asphalt walking alleys and straw-bedded cubicles. Claw-trimming was performed 5 mo before the measurements. The cows had a mean BCS of $3.4 \pm$ 0.2 (Edmonson et al., 1989). Cows' BW was assessed using a chest band, and mean BW was $692.4 \pm 81.9 \mathrm{~kg}$. At the time of measurement, the cows were in different phases of pregnancy and lactation. The animals were clinically sound, showed no signs of claw disease, had a limb confirmation without intense deviations from optimum, and had a lameness score of $\leq 2$ (Sprecher et al., 1997).

\section{Pressure Measuring System}

To analyze pressure distribution and the course of vertical ground reaction forces (vGRF), we used a foil-based piezoresistive pressure measuring system (M3200E, HoofSystem; Tekscan Inc., Boston, MA; sampling rate $100 \mathrm{~Hz}$ ). The sensors were $0.15 \mathrm{~mm}$ thick and were laminated with a 1-mm-thick rubber layer on both sides. Before calibration, they were cut to the shape of the claws, and the cut edges were sealed with silicone and fitted into leather claw shoes as insoles. These claw shoes (Figure 1) were custom-designed after the prototype published by Spielmann (1984) and had a sole thickness of $2 \mathrm{~mm}$. The sensors were conditioned with repeated loads over $300 \mathrm{~kg}$ and calibrated according to the manufacturer's instructions using a 2-point calibration with point loads at 50 and $150 \mathrm{~kg}$ per claw, equivalent to 20 and $80 \%$ of the expected load under walking cows. For calibration, we used a load applicator (Oehme et al., 2018) and a claw specimen on concrete and rubber flooring for both claw sensors separately. We conducted calibration before and after each application in each cow. Data acquisition and processing were conducted using HoofSCAN Research software (version 6.85-29; Tekscan Inc.).

\section{Experimental Setup}

Cows were fixed on a tilt table, their claws were cleaned, and a picture was taken to document the shape of the claw and the characteristics of the sole surface (Table 1). A sensor-equipped shoe was attached to the cow's left hind claw. A second claw shoe was attached under the right hind limb as a dummy to prevent an unphysiological gait and weight-shifting to the contralateral leg. The sensor cuffs were fastened to the metatarsus with an elastic bandage, and the data logger for wireless data transmission to the laptop was placed on the caudal back with a belly strap in front of the udder (Figure 2). After the cows acclimated to the equipment, they were lured with food and gently driven by walking behind them so that they could freely move at their individual but targeted walking speed in walking alleys (15 m long and $1.3 \mathrm{~m}$ wide) equipped with concrete flooring and rubber mats (KURA; Gummiwerk Kraiburg GmbH \& Co. KG, Waldkraiburg, Germany). The trial was recorded by camera (EOS 5D Mark III; Canon, Uxbridge, UK) to associate the kinetic data with the motion sequences during data analysis. Three walking sequences of $10 \mathrm{~s}$, including at least 5 regular steps, were recorded for each flooring type. Additionally, 3 standing phases for each flooring were captured, while the cows stood still with their body weight distributed equally over all legs. For data analysis, the stance phases were 
averaged over the complete measurement (static) and over 5 homogeneous steps assessed by vGRF course (dynamic). The following parameters were examined separately for the lateral and medial claws: distribution of vGRF between the claws (force balance), overall contact area, mean pressure, and maximum pressure, as well as the force-time curves of the vGRF for the dynamic measurements.

\section{Statistical Analysis}

Statistical analysis was conducted with the RStudio software (RStudio Team, 2016). Graphical assessment and the Shapiro-Wilk test were applied to determine normal distribution. Because many data frames were nonparametric, we tested statistical significance using the Wilcoxon signed-rank test. Post hoc correction was carried out with Bonferroni-Holm procedure. First, we analyzed differences in overall parameter data (overall contact area, mean pressure, maximum pressure) between the 2 tested flooring types and between the lateral and medial claws. Then, we compared the results of the static and dynamic measurements within the same test procedure. Differences were significant at $P<0.05$.

\section{RESULTS}

Because 2 separate sensors were attached under the lateral and medial hind claws of the test animals, all values were examined separately for these 2 claws. During data processing, we identified a sensor malfunction in the data of 2 cows. As well, some single static measurements had to be excluded from analysis because of unsteady force-time graphs, which indicated unsteady standing behavior. Therefore, analysis was carried out on 8 animals with complete data sets. For some, only 2 repeated measurements per flooring while standing were assessed.

\section{Static Measurements}

On both tested flooring types, the lateral claws of the left hind limbs were loaded an average of 1.3 to 1.5 times more than the medial claws. We found no significant differences in force balance between concrete and rubber flooring. The average loaded area was 35.17 to $40.60 \mathrm{~cm}^{2}$ per claw and did not differ significantly between concrete and rubber flooring (Table 2). The mean and maximum pressure values were significantly higher on concrete than on rubber flooring (Figure 3). We found no significant differences between the lateral and medial claws for the analyzed parameters $(P>$ $0.05)$.

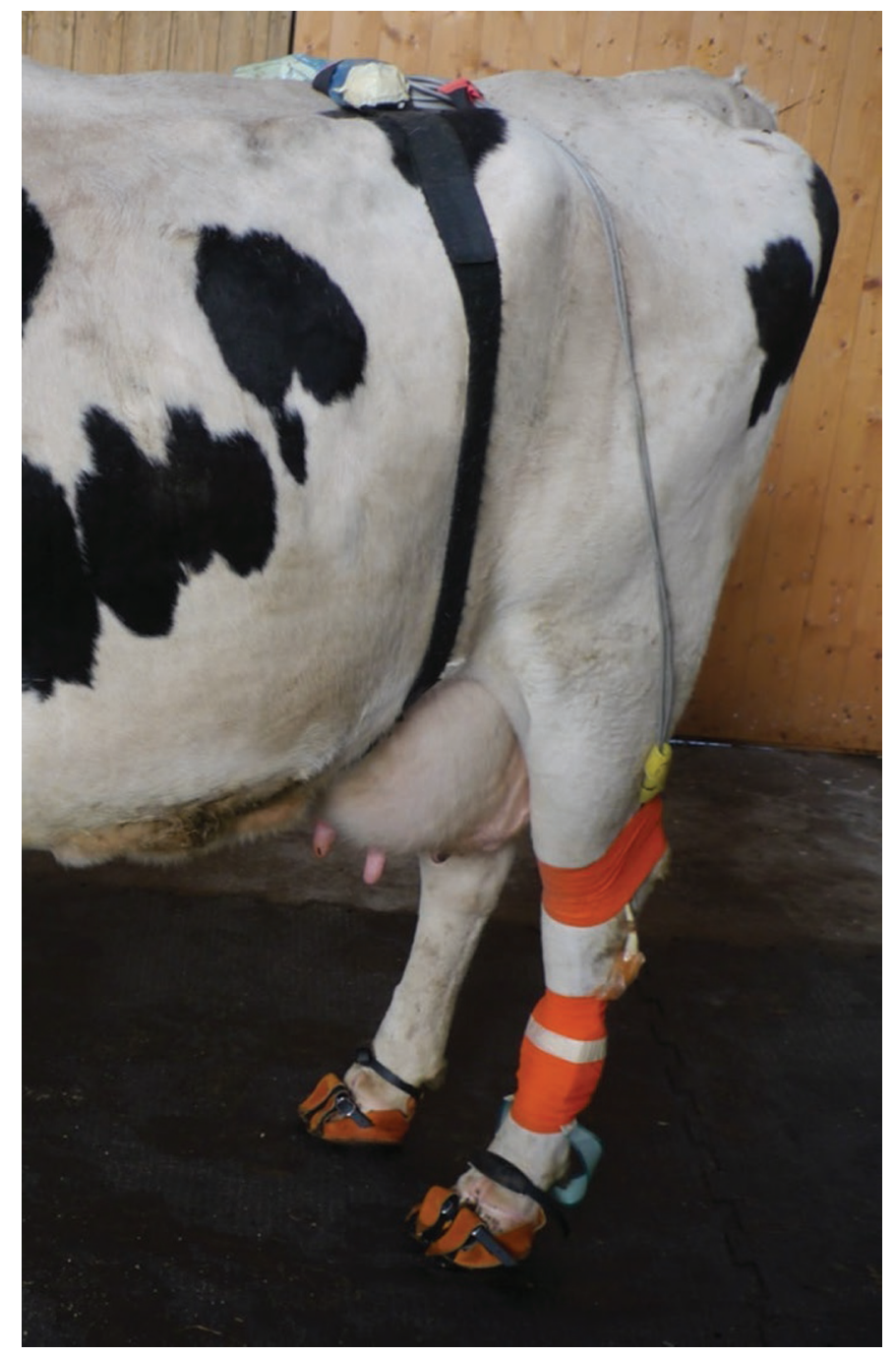

Figure 2. Fixation of measuring devices at the left hind limb and on the back.

\section{Dynamic Measurements}

Pressure Distribution. Similar to the static measurements, the lateral claws bore a higher vertical load than the medial claws during walking and showed no significant differences between the tested flooring types. The mean loaded area was approximately $4 \mathrm{~cm}^{2}$ larger

Table 1. Claw sole dimensions ${ }^{1}$ analyzed digitally based on photographic claw documentation (mean $\pm \mathrm{SD}$ )

\begin{tabular}{lrr}
\hline Parameter & Lateral claw & Medial claw \\
\hline Sole length $(\mathrm{cm})$ & $11.86 \pm 0.84$ & $11.22 \pm 0.78$ \\
Sole width $(\mathrm{cm})$ & $4.76 \pm 0.41$ & $4.02 \pm 0.22$ \\
Sole surface area $\left(\mathrm{cm}^{2}\right)$ & $46.04 \pm 5.80$ & $39.82 \pm 3.88$ \\
\hline
\end{tabular}

${ }^{1}$ After Nuss and Paulus, 2006. 
Table 2. Parameters of the static measurements on concrete and rubber flooring (mean $\pm \mathrm{SD}$ )

\begin{tabular}{|c|c|c|c|c|}
\hline Parameter $^{1}$ & Claw & Concrete & Rubber & $P$-value \\
\hline \multirow[t]{2}{*}{ vGRF (N) } & Lateral & $1,294.0 \pm 274.5$ & $1,253.3 \pm 336.1$ & Not tested \\
\hline & Medial & $1,009.3 \pm 142.9$ & $865.4 \pm 225.4$ & Not tested \\
\hline Force balance & Lateral/medial & $1.34 \pm 0.34^{\mathrm{a}}$ & $1.53 \pm 0.45^{\mathrm{a}}$ & 0.164 \\
\hline \multirow{2}{*}{$\mathrm{A}_{\text {total }}\left(\mathrm{cm}^{2}\right)$} & Lateral & $37.00 \pm 4.76^{\mathrm{a}}$ & $40.60 \pm 4.97^{\mathrm{a}}$ & 0.164 \\
\hline & Medial & $35.17 \pm 9.21^{\mathrm{a}}$ & $35.92 \pm 10.88^{\mathrm{a}}$ & 0.230 \\
\hline \multirow[t]{2}{*}{$\mathrm{P}_{\mathrm{av}}\left(\mathrm{N} / \mathrm{cm}^{2}\right)$} & Lateral & $36.32 \pm 7.77^{\mathrm{a}}$ & $30.82 \pm 6.86^{\mathrm{b}}$ & 0.023 \\
\hline & Medial & $31.18 \pm 80.67^{\mathrm{a}}$ & $25.23 \pm 5.18^{\mathrm{b}}$ & 0.023 \\
\hline $\mathrm{P}_{\max }\left(\mathrm{N} / \mathrm{cm}^{2}\right)$ & & $98.79 \pm 14.49^{\mathrm{a}}$ & $68.95 \pm 12.03^{\mathrm{b}}$ & 0.023 \\
\hline
\end{tabular}

${ }^{\mathrm{a}, \mathrm{b}}$ Values within a row with different superscripts differ significantly $(P<0.05)$.

${ }^{1} \mathrm{~A}_{\text {total }}=$ loaded area; $\mathrm{P}_{\mathrm{av}}=$ mean pressure; $\mathrm{P}_{\max }=$ maximum pressure; vGRF = vertical ground reaction force.

on rubber flooring compared with concrete (Table 3). Accordingly, mean pressures were higher on concrete than on rubber flooring. The maximum pressure values were also significantly higher on concrete than on rubber flooring (Figure 4). Similar to the static measurements, we found no differences between the lateral and medial claws for these parameters $(P>0.05)$.

Force-Time Curves. We assessed the shapes of the force-time curves for local maxima and compared them between the 2 tested flooring types, as well as between the lateral and medial claws. Most curves (lateral 30/48, medial 35/48) showed 2 local maxima, but in some graphs the second peak was not obviously traceable. For some cows and in some measurements, the force-time graphs described a plateau or had only 1 maximum. If local maxima existed, they were located at $29.3 \pm 4.6 \%$ and $79.2 \pm 2.9 \%$ of the average stance phase (Figure 5).

We could not detect general differences in the forcetime curves between concrete and rubber flooring.
The curve progressions were predominantly consistent among the repeated measures of a single claw. However, we found substantial differences between tested cows, as well as between the lateral and medial claws. In some cases, the graphs of the lateral and medial claws even showed inverse curve progressions, meaning 1 claw had the highest peak in the first third of the stance phase when located in the last third in the other claw (Figure $6)$.

\section{Comparison of Static and Dynamic Measurements}

We found no significant differences for any parameter between the static and dynamic measurements. However, the loaded area of the lateral claw on both flooring types and the medial claw on rubber flooring tended to be larger while walking than while standing $(P=$ 0.109). For the mean and maximum pressure loads, the values tended to be higher in the dynamic than in the static measurements $(P=0.109)$.
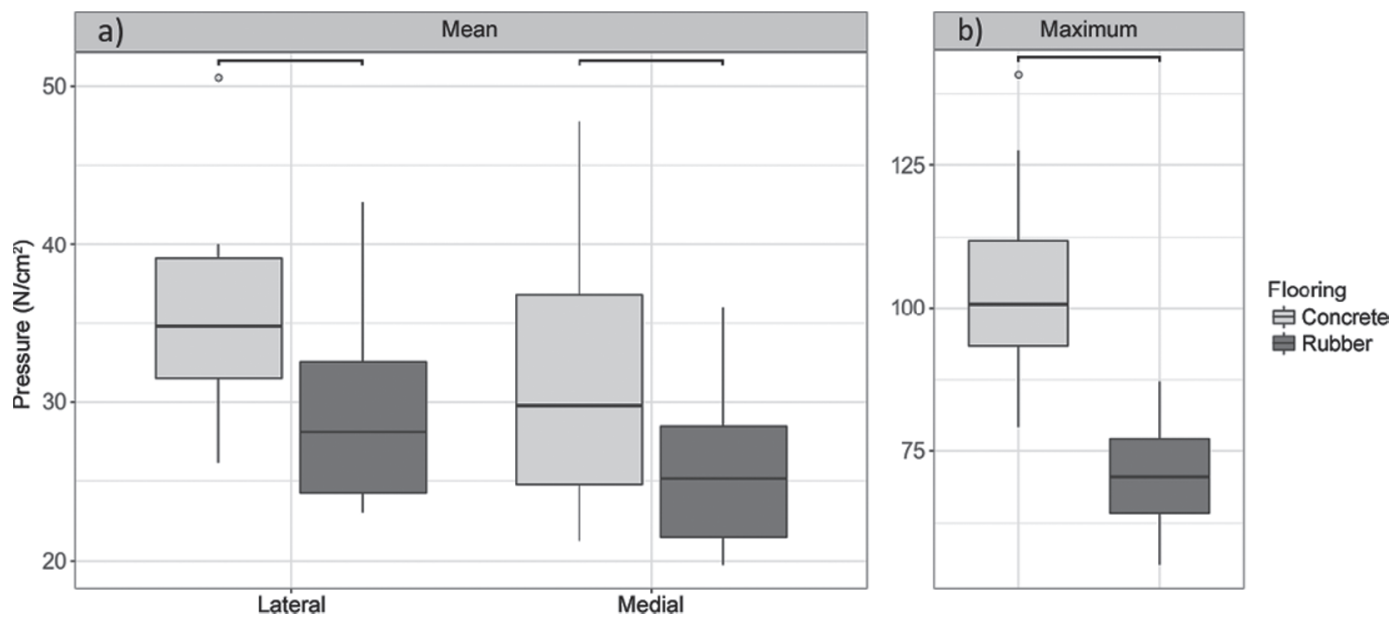

Figure 3. Boxplots of (a) mean pressure, and (b) maximum pressure of the static measurements on concrete and rubber flooring. Horizontal lines at the top indicate significant differences with $P<0.05$ between the flooring types. The box is delimited by the first and third quartile; the line within the box represents the median; the end of the whisker represents highest and lowest values within 1.5 interquartile range; and dots represent outliers. 
Table 3. Parameters averaged over the total stance phase of the dynamic measurements on concrete and rubber flooring (mean $\pm \mathrm{SD})$

\begin{tabular}{|c|c|c|c|c|}
\hline Parameter $^{1}$ & Claw & Concrete & Rubber & $P$-value \\
\hline \multirow{2}{*}{ vGRF (N) } & Lateral & $2,224.1 \pm 223.4$ & $2,166.8 \pm 243.1$ & Not tested \\
\hline & Medial & $1,289.5 \pm 271.3$ & $1,274.3 \pm 200.4$ & Not tested \\
\hline Force balance & Lateral/medial & $1.80 \pm 0.38^{\mathrm{a}}$ & $1.74 \pm 0.29^{\mathrm{a}}$ & 0.220 \\
\hline \multirow[t]{2}{*}{$\mathrm{A}_{\text {total }}\left(\mathrm{cm}^{2}\right)$} & Lateral & $47.95 \pm 4.45^{\mathrm{a}}$ & $51.86 \pm 3.51^{\mathrm{b}}$ & 0.023 \\
\hline & Medial & $40.74 \pm 9.85^{\mathrm{a}}$ & $44.33 \pm 7.65^{\mathrm{b}}$ & 0.039 \\
\hline \multirow[t]{2}{*}{$\mathrm{P}_{\mathrm{av}}\left(\mathrm{N} / \mathrm{cm}^{2}\right)$} & Lateral & $57.33 \pm 11.77^{\mathrm{a}}$ & $46.24 \pm 6.83^{\mathrm{b}}$ & 0.023 \\
\hline & Medial & $46.15 \pm 13.21^{\mathrm{a}}$ & $36.40 \pm 7.55^{\mathrm{b}}$ & 0.023 \\
\hline $\mathrm{P}_{\max }\left(\mathrm{N} / \mathrm{cm}^{2}\right)$ & & $150.45 \pm 20.87^{\mathrm{a}}$ & $101.23 \pm 7.43^{\mathrm{b}}$ & 0.023 \\
\hline
\end{tabular}

${ }^{\mathrm{a}, \mathrm{b}}$ Values within a row with different superscripts differed significantly $(P<0.05)$.

${ }^{1} \mathrm{~A}_{\text {total }}=$ loaded area; $\mathrm{P}_{\mathrm{av}}=$ mean pressure; $\mathrm{P}_{\max }=$ maximum pressure; vGRF $=$ vertical ground reaction force.

\section{DISCUSSION}

\section{Methodological Considerations}

In this study, we applied the Tekscan HoofSystem under live dairy cows' claws for the first time. This system has been used for equine kinetic research previously (Lange et al., 2012; Al Naem, 2014; Hagen et al., 2016) and has been recommended for scientific and clinical applications (Lange et al., 2012). Most authors analyzed and compared the kinetic data in a relative way, because the absolute vGRF output of the sensor foils was less accurate than that achieved with force plates (Sumiya et al., 1998; Morin et al., 2001; Perino et al., 2007). However, this negative effect can be avoided by appropriate conditioning and calibration before the trial (Brimacombe et al., 2009). We calibrated the sensors continuously before and after every usage to guarantee the same conditions for all measurements. Because we used separate sensor foils for the lateral and medial claws, they also had to be calibrated separately, result- ing in 2 different calibration files. Although Luo et al. (1998) noted considerable disparities between sensors, this finding can be disregarded because of the consistent calibration protocol used in the current study. We used the same calibration file, generated with expected loads while walking, for static and dynamic measures to obtain better comparability between measurements. This may have led to overestimated pressure values in the static measurements because of the higher calibration range compared with the actual loads while standing (Hsiao et al., 2002). In some data, the medial claws carried a considerably higher load on concrete than on rubber flooring. This variability in loading patterns was also shown by Fischer (2006) and may have influenced the differences in pressure loads of the medial claw between the 2 flooring types to a certain degree, so these findings should be interpreted carefully. Because the 2 claws were recorded using separate sensors, the lateral claws were analyzed separately from the medial claws. The mean difference in loading between the flooring types was $40.7 \mathrm{~N}$ (static) to $57.3 \mathrm{~N}$ (dynamic) in the
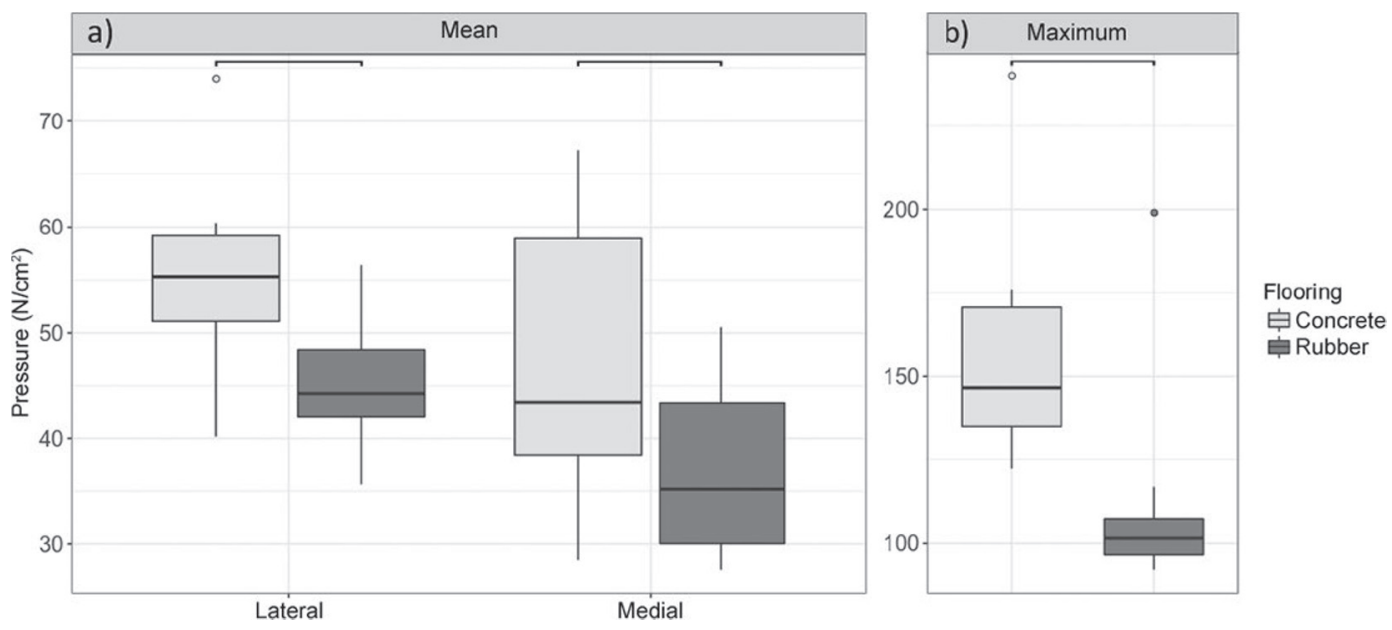

Figure 4. Boxplots of (a) mean pressure, and (b) maximum pressure of the dynamic measurements on concrete and rubber flooring. Horizontal lines at the top indicate significant differences with $P<0.05$ between the flooring types. The box is delimited by the first and third quartile; the line within the box represents the median; the end of the whisker represents highest and lowest values within 1.5 interquartile range; and dots represent outliers. 
lateral claws, corresponding to an error of about $3 \%$. Results for the lateral claw can therefore be assumed to be valid.

The sensor foils were applicable for use in live dairy cows and some could be used repeatedly. But despite the silicone seal on the cutting edge, the sensors were damaged due to moisture in the space between the 2 foil layers. As well, because the original seal and connection were lost with cutting the sensors to the shape of the claws, the 2 layers separated in some sensors, especially after sudden motion or turning, because of associated high shear forces. A factory-produced sensor foil in a claw shape and with different sizes would be beneficial for maintaining connection of the sensor layers and ensuring higher resistance to moisture and shear forces. However, such a sensor is not yet commercially available.

The leather claw shoes were appropriate for sensor fixation under the claws. The material was resilient enough and resisted tensile strain at the shaft and abrasion at the sole. However, the leather sole might have been disadvantageous because of its soft and elastic properties, which allowed the claws to sink in on hard concrete flooring and may have attenuated the differences between flooring types. For subsequent investigations, it might be expedient to replace this sole with a different thin, robust, but still slip-resistant material.
After a short habituation time, the cables, cuffs and data logger at the leg and back did not noticeably affect animals' standing and walking behavior. The length of the walkway was sufficient for recording at least 5 homogeneous steps, required for representative kinetic analysis (Schamhardt, 1996).

Although claw-trimming was conducted 5 mo prior to the study, claws were relatively uniform and had a smooth sole because of the mastic asphalt flooring, and the slopes were broadly grown out. Measurements closer to claw-trimming would have been preferable, but several kinetic studies on live dairy cows with a similar claw-trimming interval can be consulted for comparison (Gerwing, 2003; Fischer, 2006; Telezhenko et al., 2008; Bergsten et al., 2015).

We selected and averaged 5 analyzable steps using video footage and force-time curves. We could not analyze single stance-phase sections, because the sampling rate of the wireless data logger could not exceed $113.9 \mathrm{~Hz}$ and the sensors could capture only vertical components of ground reaction forces. Nevertheless, the selected sampling rate of $100 \mathrm{~Hz}$ was adequate for assessing the kinetic patterns of an averaged walking stance phase (Baumann et al., 1994).

In this study, for the first time, we evaluated the force-time curves averaged over 5 steps separately for lateral and medial claws. Because of substantial interin-

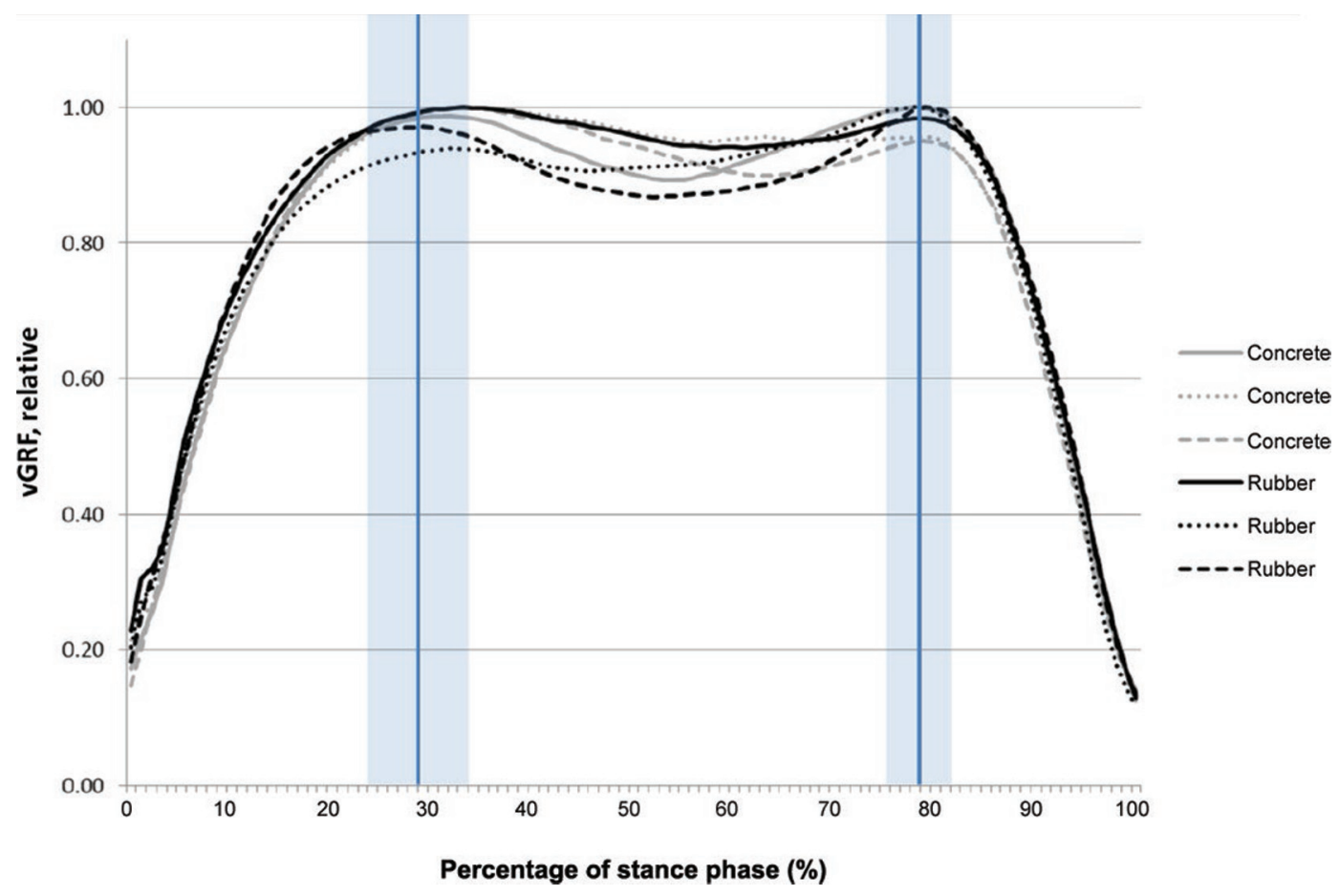

Figure 5. Force-time curves averaged over 5 steps of 1 cow's lateral hind claw on both tested flooring types (concrete and rubber) with 3 repeated measurements each. Vertical lines indicate means and standard deviations of local maxima localizations. vGRF $=$ vertical ground reaction force. 
a)

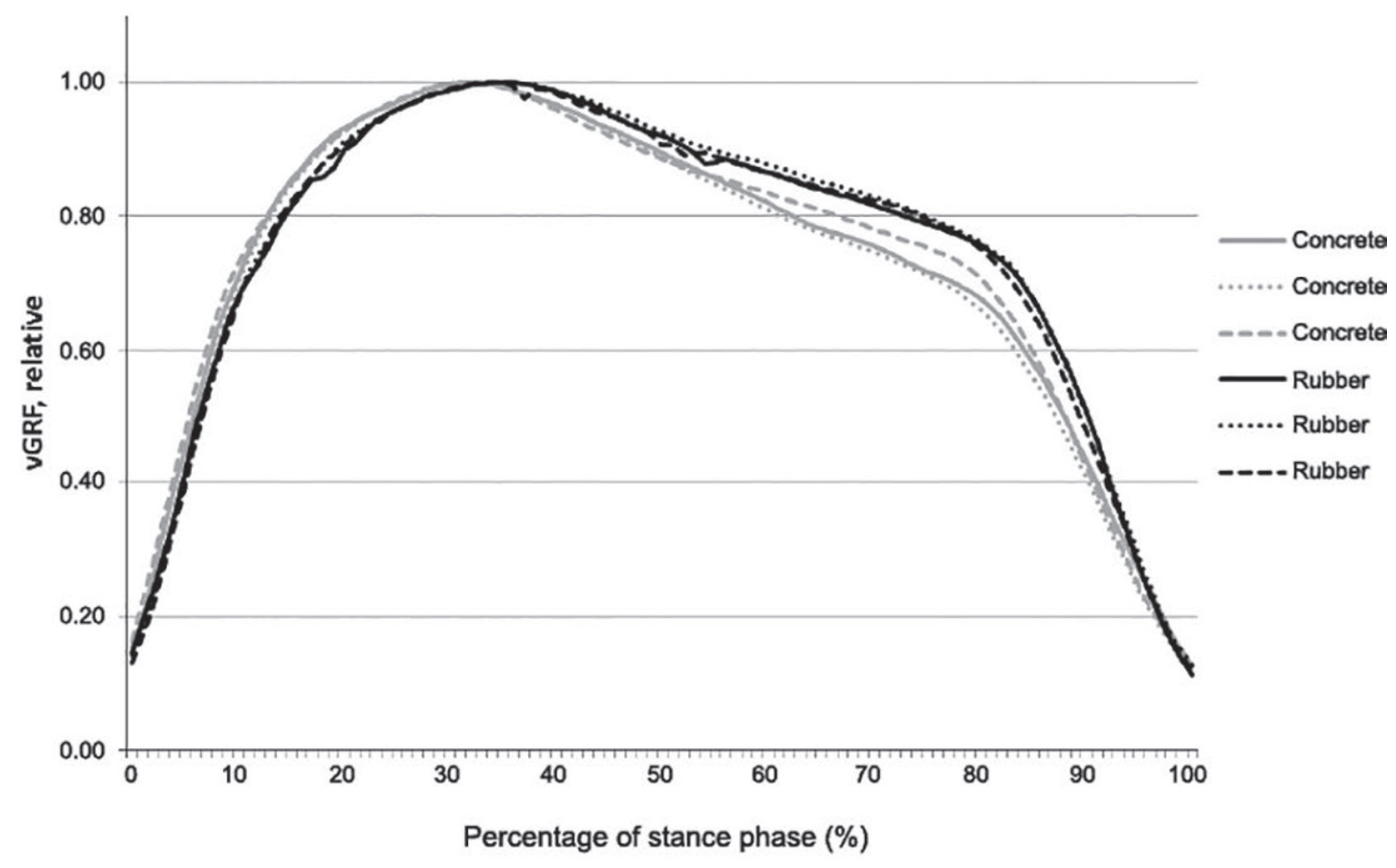

b)

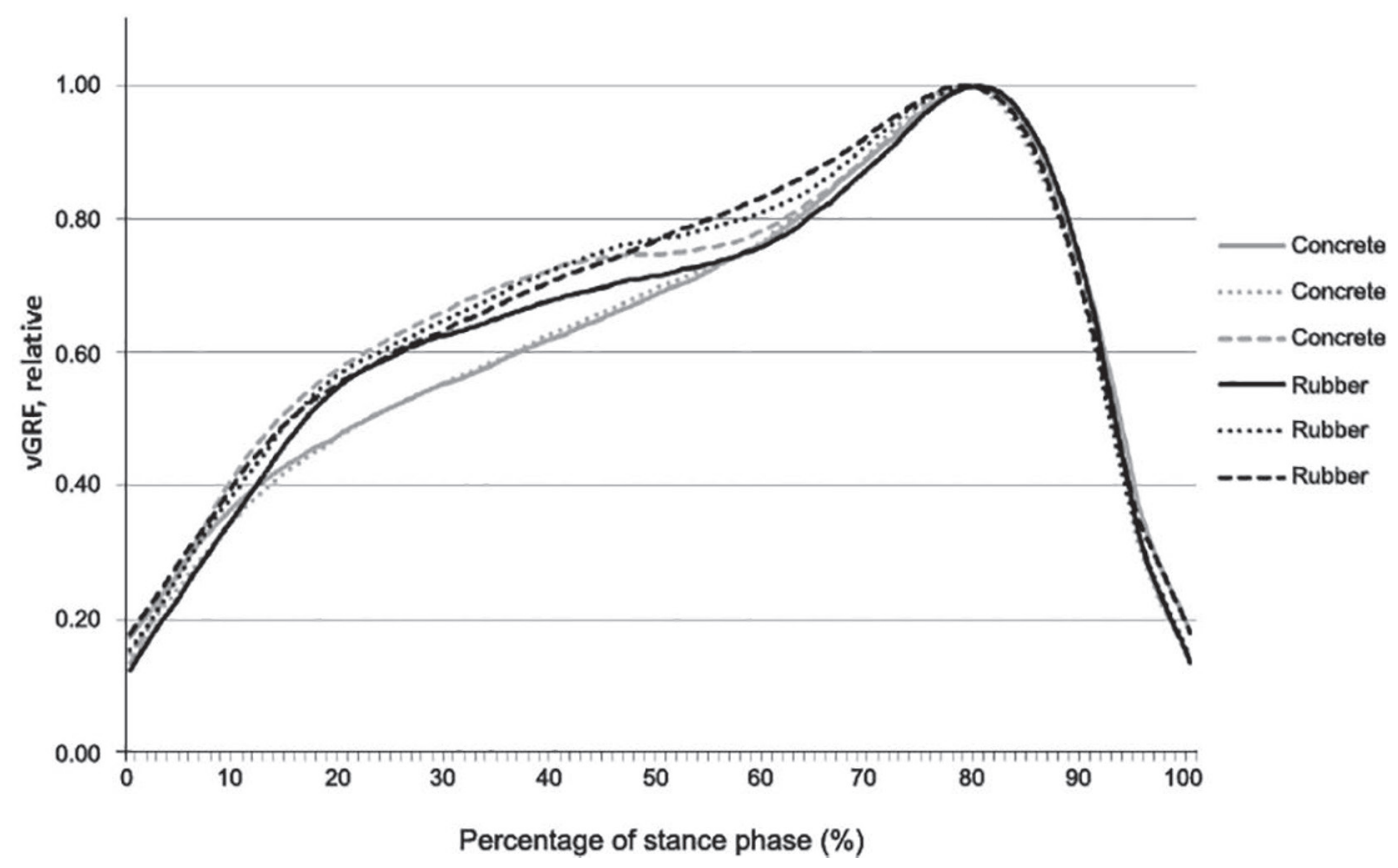

Figure 6. Force-time curves averaged over 5 steps of 1 cow's (a) lateral and (b) medial claws on both tested flooring types (concrete and rubber) with 3 repeated measurements each, showing inverse curve progressions between the 2 claws. vGRF $=$ vertical ground reaction force.

dividual variances and a limited number of tested cows, we assessed the graphs visually. For more detailed analysis, more animals would be required. Still, with the assessed force-time curves in the current study, we were able to draw first comparisons with published forcetime analyses of walking cows with regard to biphasic courses and the location of local maxima (Meyer, 2006; Walker et al., 2010; Nuss et al., 2015). 


\section{Pressure Distribution}

While standing, the lateral claws carried about $50 \%$ more load than the medial claws. This finding was in accordance with those of Gerwing (2003), Fischer (2006), and the asphalt group in the study by Telezhenko et al. (2008), with a similar interval after claw-trimming. Conversely, the loaded area was considerably larger than in previous studies. On concrete, the loaded area of both claws (mean $72.17 \mathrm{~cm}^{2}$ ) was 20 to $25 \mathrm{~cm}^{2}$ larger than that shown by Fischer (2006) and Gerwing (2003), and twice as high as the areas found by Telezhenko et al. (2008) and Bergsten et al. (2015). These remarkable deviations from previous studies, as well as the partly missing significant differences between concrete and rubber flooring in the current study, may have been because of the leather soles of the claw shoes, and to the thin rubber sheets covering the sensors. A soft and elastic layer between claw and flooring may have diminished the effect, especially of the hard concrete flooring, and induced a larger loaded area. As well, the missing slope because of keeping the cows on abrasive mastic asphalt flooring led to a larger sole in itself, also observed by Spielmann (1990). The captured average pressures while standing were in accordance with the findings of Fischer (2006) and Gerwing (2003), who found mean pressures of 24.8 and $28.1 \mathrm{~N} / \mathrm{cm}^{2}$, respectively. Both average and maximum pressure values were in the same range as those shown by Bergsten et al. (2015). Some studies observed predominantly lower pressure loads (Telezhenko et al., 2008), and others showed higher loads (van der Tol et al., 2004).

Under walking cows' claws, the force balance in the current study was comparable to that of the stance phase's second half in van der Tol et al. (2003). As we have stated, the loaded area in the current study was distinctly larger than in previous investigations, but under dynamic conditions it was even larger on rubber flooring compared with concrete. Mean and maximum pressure loads were in accordance with the results of the dynamic kinetic study of van der Tol et al. (2003). In contrast, the average pressure values found by Carvalho (2004) were substantially lower than in the current study, although in that study, the pressure loads under trimmed claws were higher than under non-trimmed claws, contradictory to the findings of other authors (Gerwing, 2003; van der Tol et al., 2004; Zeiner et al., 2007). No further references to pressure distribution under walking cows have been published, and because the results differ remarkably, it will be necessary to carry out additional investigations on more animals to gather sufficient data to work on further questions.

Comparing the results of the static and dynamic measurements, we assumed a larger loaded area and higher pressure loads during walking due to the occurring impulse. Nevertheless, the results only tended to be greater in the dynamic measurements compared with the static values. The lack of significant difference may again have originated from the soft leather sole of the claw shoe, which may have diminished the contrast between the concrete and rubber flooring, as well as between the static and dynamic measurements. Another cause for the lack of difference could have been the use of the same calibration data for standing and walking measurements, leading to an overestimation of static loads (Hsiao et al., 2002). It may be reasonable to use separate calibration data for static and dynamic loads in subsequent studies; the results of the static measures in this study should be interpreted carefully.

In both standing and walking measurements, the average and maximum pressure loads were significantly lower on rubber flooring compared with concrete. Because the conditions for both flooring types were identical, these differences can be considered valid. We assume, considering the findings of a previous ex vivo study (Oehme et al., 2018), that the mechanical load to the sole of the claws can be verifiably and significantly reduced on rubber flooring compared with concrete.

\section{Force-Time Curves}

The sensor foils captured force-time graphs for vGRF, and they could be analyzed for lateral and medial claws separately. We observed mainly biphasic curve progressions, already shown in previous studies analyzing force-time curves of bovine hind limbs (Meyer, 2006; Walker et al., 2010; Nuss et al., 2015). On average, local maxima occurred at 29.3 and $79.2 \%$ of the stance phase in the current study. Other authors observed these peaks somewhat earlier in the stance phase, at 25 and $75 \%$ (Walker et al., 2010) or 23 and $70 \%$ (Nuss et al., 2015). Nevertheless, 2 vertical force peaks at approximately the first and the last fourth of the stance phase of dairy cows' hind limbs can be assumed.

We could not observe general differences in forcetime curves between the 2 tested flooring types, but we determined noticeable interindividual disparities of curve shapes, as shown by Walker et al. (2010). Also, by comparing the lateral and medial claws, distinct varieties occurred, and within some legs even an inverse progression in the lateral versus the medial claw. This may be explained by earlier studies, which showed an earlier floor contact of the lateral claw (Meyer, 2006) and a weight shift to the medial claw during the stance phase (van der Tol et al., 2003). Because the force-time graphs of both claws were analyzed together in previous investigations, this effect has not been observed before. 
It would be reasonable to carry out further studies on more animals to validate these initial results. Furthermore, an investigation of pressure loads on pasture as natural reference ground should be conducted with this system to compare it with commercial rubber flooring, as well as concrete or mastic asphalt.

\section{CONCLUSIONS}

The HoofSystem was applicable under the claws of dairy cows and allowed for direct measurement of clawfloor interaction in live dairy cows on different flooring types for the first time. The claws bore lower pressure loads on rubber flooring compared with concrete, which may lead to a reduction of mechanically induced claw lesions. We also captured separate force-time curves with this measurement system, which showed distinct differences between lateral and medial claws that may be validated in further investigations. With this measurement technique, future studies on the effect of claw-trimming methods, alternative flooring systems, and extreme load situations (e.g., while mounting) may be conducted, and an objective evaluation of the effects of trimming and its quality will also be possible.

\section{ACKNOWLEDGMENTS}

The project was supported by funds from the Landwirtschaftliche Rentenbank (Frankfurt am Main, Germany). Benjamin Oehme received a scholarship from the Klaus Murmann Fellowship Program of the Foundation of German Business (SDW). The authors sincerely thank Nicole Röhrmann and Monique Weiss from the Institute of Veterinary Anatomy, Histology and Embryology, Faculty of Veterinary Medicine, Leipzig University, for their support in data acquisition, and Kai Hainke for assistance with statistical analysis and visualization.

\section{REFERENCES}

Al Naem, M. 2014. Untersuchungen zur Hufrehe bei Pferden mit Hilfe des HufScan ${ }^{\circledR}$-Systems. DVM Diss. Faculty of Veterinary Medicine, Equine Clinic - Equine Surgery, Justus-Liebig-University, Gießen, Germany. [In German]

Barker, Z. E., K. A. Leach, H. R. Whay, N. J. Bell, and D. C. Main. 2010. Assessment of lameness prevalence and associated risk factors in dairy herds in England and Wales. J. Dairy Sci. 93:932-941. https://doi.org/10.3168/jds.2009-2309.

Baumann, W., N. Müller, and G. Brust. 1994. Grundlegende Begriffe und Anwendungsaspekte der elektronischen Druckverteilungsmessung am Fuß. Med. Orthop. Tech. 114:6-13. [In German]

Bendel, J. 2005. Auswirkungen von elastischen Bodenbelägen auf das Verhalten von Milchrindern im Laufstall. DVM Diss. Department of Veterinary Science, Chair of Animal Welfare, Ethology, Animal Hygiene, and Animal Housing, Faculty of Veterinary Medicine, Ludwig-Maximilians University, Munich, Germany. [In German]
Benz, B. 2002. Elastische Beläge für Betonspaltenböden in Liegeboxenlaufställen. Diss. Institute for Agricultural Engineering, University of Hohenheim, Germany. [In German]

Bergsten, C., E. Telezhenko, and M. Ventorp. 2015. Influence of soft or hard floors before and after first calving on dairy heifer locomotion, claw and leg health. Animals (Basel) 5:662-686. https://doi .org/10.3390/ani5030378.

Bicalho, R. C., L. D. Warnick, and C. L. Guard. 2008. Strategies to analyze milk losses caused by diseases with potential incidence throughout the lactation: A lameness example. J. Dairy Sci. 91:2653-2661. https://doi.org/10.3168/jds.2007-0744.

Boyle, L. A., J. F. Mee, and P. J. Kiernan. 2007. The effect of rubber versus concrete passageways in cubicle housing on claw health and reproduction of pluriparous dairy cows. Appl. Anim. Behav. Sci. 106:1-12. https://doi.org/10.1016/j.applanim.2006.07.011.

Brimacombe, J. M., D. R. Wilson, A. J. Hodgson, K. C. T. Ho, and C. Anglin. 2009. Effect of calibration method on Tekscan sensor accuracy. J. Biomech. Eng. 131:34503. https://doi.org/10.1115/1 .3005165 .

Carvalho, V. 2004. Effects of trimming on dairy-cow hoof-pressure distributions and weight-bearing dynamics during stance phase. $\mathrm{PhD}$ Thesis. Department of Agricultural and Biological Engineering, University of Florida, Gainesville.

Cha, E., J. A. Hertl, D. Bar, and Y. T. Gröhn. 2010. The cost of different types of lameness in dairy cows calculated by dynamic programming. Prev. Vet. Med. 97:1-8. https://doi.org/10.1016/j prevetmed.2010.07.011.

De Belie, N., and E. Rombaut. 2003. Characterisation of claw-floor contact pressures for standing cattle and the dependency on concrete roughness. Biosyst. Eng. 85:339-346. https://doi.org/10 .1016/S1537-5110(03)00064-3.

Edmonson, A. J., I. J. Lean, L. D. Weaver, T. Farver, and G. Webster. 1989. A body condition scoring chart for Holstein dairy cows. J. Dairy Sci. 72:68-78. https://doi.org/10.3168/jds.S0022 -0302(89)79081-0.

Eicher, S. D., D. C. Lay, J. D. Arthington, and M. M. Schutz. 2013. Effects of rubber flooring during the first 2 lactations on production, locomotion, hoof health, immune functions, and stress. J. Dairy Sci. 96:3639-3651. https://doi.org/10.3168/jds.2012-6049.

Fischer, L. 2006. Analyse der Druckverteilung unter den Klauen bei Kühen der Rasse Deutsche Holsteins. DVM Diss. Clinic for Cattle, School of Veterinary Medicine Hannover, Germany. University of Hanover, Germany. [In German]

Fjeldaas, T., A. M. Sogstad, and O. Osterås. 2011. Locomotion and claw disorders in Norwegian dairy cows housed in freestalls with slatted concrete, solid concrete, or solid rubber flooring in the alleys. J. Dairy Sci. 94:1243-1255. https://doi.org/10.3168/jds.2010 -3173 .

Flower, F. C., A. M. de Passillé, D. M. Weary, D. J. Sanderson, and J. Rushen. 2007. Softer, higher-friction flooring improves gait of cows with and without sole ulcers. J. Dairy Sci. 90:1235-1242. https:// doi.org/10.3168/jds.S0022-0302(07)71612-0.

Franck, A., G. Cocquyt, P. Simoens, and N. De Belie. 2006. Biomechanical properties of bovine claw horn. Biosyst. Eng. 93:459-467. https://doi.org/10.1016/j.biosystemseng.2006.01.007.

Franck, A., and N. De Belie. 2006. Concrete floor-bovine claw contact pressures related to floor roughness and deformation of the claw. J. Dairy Sci. 89:2952-2964. https://doi.org/10.3168/jds.S0022 -0302(06)72567-X.

Franck, A., B. Verhegghe, and N. De Belie. 2008. The effect of concrete floor roughness on bovine claws using finite element analysis. J. Dairy Sci. 91:182-192. https://doi.org/10.3168/jds.2007-0211.

Gerwing, T. H. 2003. Beeinflussung der Lastverteilung durch Klauenpflege innerhalb der Einzelklauen und der Klauenpaare der Hintergliedmaßen von schwarzbunten Milchkühen der Rasse Deutsche Holsteins. DVM Diss. Clinic for Cattle, School of Veterinary Medicine Hannover, Germany. [In German]

Hagen, J., M. Hüppler, F. S. Häfner, S. M. Geiger, and D. Mäder. 2016. Modifying horseshoes in the mediolateral plane: Effects of side wedge, wide branch, and unilateral roller shoes on the phalan- 
geal alignment, pressure forces, and the footing pattern. J. Equine Vet. Sci. 37:77-85. https://doi.org/10.1016/j.jevs.2015.12.001.

Hilger, J., and U. Passarge. 2018. Jahresbericht 2017. Sächsischer Landeskontrollverband e.V., Niederwiesa, Germany. [In German]

Hinterhofer, C., H. Haider, V. Apprich, J. C. Ferguson, S. N. Collins, and C. Stanek. 2009. Development of a twenty-one-component finite element distal hind limb model: stress and strain in bovine digit structures as a result of loading on different floorings. J. Dairy Sci. 92:972-979. https://doi.org/10.3168/jds.2008-1605.

Hsiao, H., J. Guan, and M. Weatherly. 2002. Accuracy and precision of two in-shoe pressure measurement systems. Ergonomics 45:537555. https://doi.org/10.1080/00140130210136963.

Jungbluth, T., B. Benz, and H. Wandel. 2003. Soft walking areas in loose housing systems for dairy cows. Pages 171-177 in Fifth Int. Dairy Housing Proc., Fort Worth, TX. Am. Soc. Agric. Biol. Eng., St. Joseph, MI

Knott, L., J. F. Tarlton, H. Craft, and A. J. F. Webster. 2007. Effects of housing, parturition and diet change on the biochemistry and biomechanics of the support structures of the hoof of dairy heifers. Vet. J. 174:277-287. https://doi.org/10.1016/j.tvjl.2006.09.007.

Kremer, P. V., S. Nueske, A. M. Scholz, and M. Foerster. 2007. Comparison of claw health and milk yield in dairy cows on elastic or concrete flooring. J. Dairy Sci. 90:4603-4611. https://doi.org/10 $.3168 /$ jds. 2006-549.

Lange, C., A. Kattelans, K. Rohn, M. Lüpke, H. P. Brückner, and P. Stadler. 2012. Die kinetische Untersuchung der Fußung, der Belastung des Hufes und des Abrollvorganges an den Vordergliedmaßen von Pferden im Schritt und im Trab auf dem Laufband mit dem Hoof ${ }^{\text {TM }}$-System $\left(\right.$ Tekscan $\left.^{\boxplus}\right)$. Pferdeheilkunde 28:538-547. [In German]

Liang, D., L. M. Arnold, C. J. Stowe, R. J. Harmon, and J. M. Bewley. 2017. Estimating US dairy clinical disease costs with a stochastic simulation model. J. Dairy Sci. 100:1472-1486. https://doi.org/10 .3168/jds.2016-11565.

Luo, Z. P., L. J. Berglund, and K. N. An. 1998. Validation of F-Scan pressure sensor system: A technical note. J. Rehabil. Res. Dev. $35: 186-191$.

Meyer, S. W. 2006. Hochfrequenzkinematographische Untersuchungen des Fussungsvorganges von Rindern auf dem Laufband. DVM Diss. Department of Farm Animals, Vetsuisse-Faculty, Zurich, Switzerland. [In German]

Morin, E. L., J. T. Bryant, S. A. Reid, and R. A. Whiteside. 2001. Calibration issues of Tekscan systems for human pressure assessment. Pages 24-1-24-7 in Soldier Mobility: Innovations in Load Carriage System Design and Evaluation, Kingston, Canada. NATO, Neuilly-sur-Seine, France.

Mülling, C., and C. J. Lischer. 2002. New aspects on etiology and pathogenesis of laminitis in cattle. Pages 236-247 in Proc. XXII World Buiatrics Congress, Hannover, Germany. M. Kaske, H. Scholz, and M. Höltershinken, ed. World Association for Buiatrics, Saint-Hyacinthe, Quebec, Canada.

Nuss, K., and N. Paulus. 2006. Measurements of claw dimensions in cows before and after functional trimming: A post-mortem study. Vet. J. 172:284-292. https://doi.org/10.1016/j.tvjl.2005.04.031.

Nuss, K., N. M. Waldern, M. A. Weishaupt, and T. Wiestner. 2015. Kinetische Auswertung des Schrittes von Jungrindern und Kühen auf einem instrumentierten Laufband. Tierarztl. Prax. Ausg. G Grosstiere Nutztiere 43:73-80. [In German] https://doi.org/10 15653/TPG-140517.

Oehme, B., S. M. Geiger, S. Grund, K. Hainke, J. Munzel, and C. K. W. Mülling. 2018. Effect of different flooring types on pressure distribution under the bovine claw-An ex vivo study. BMC Vet. Res. 14:259. https://doi.org/10.1186/s12917-018-1579-9.

Perino, V. V., C. E. Kawcak, D. D. Frisbie, R. F. Reiser, and C. W. McIlwraith. 2007. The accuracy and precision of an equine in-shoe pressure measurement system as a tool for gait analysis. J. Equine Vet. Sci. 27:161-166. https://doi.org/10.1016/j.jevs.2007.02.006.
Platz, S., F. Ahrens, J. Bendel, H. H. D. Meyer, and M. H. Erhard. 2008. What happens with cow behavior when replacing concrete slatted floor by rubber coating: A case study. J. Dairy Sci. 91:9991004. https://doi.org/10.3168/jds.2007-0584.

RStudio Team. 2016. RStudio: Integrated Development Environment for R. R Studio Inc., Boston, MA.

Rushen, J., and A. M. de Passilé. 2006. Effects of roughness and compressibility of flooring on cow locomotion. J. Dairy Sci. 89:29652972. https://doi.org/10.3168/jds.S0022-0302(06)72568-1.

Samel, M. 2005. Gummibeschichtete Laufflächen für Milchkühe und deren Einfluss auf Klauenwachstumsparameter und Klauengesundheit im Vergleich zu betonierten Laufflächen. DVM Diss. Clinic for Cattle, University of Hanover, Germany. [In German]

Schamhardt, H. C. 1996. Quantitative analysis of equine locomotion. Pages 189-211 in Measuring Movement and Locomotion: From Invertebrates to Humans. K.-P. Ossenkopp, M. Kavakiers, and P. R. Sanberg, ed. Springer, Heidelberg, Germany.

Spielmann, C. 1984. Konstruktion und Bau einer Messanlage zur Kraft- und Druckverteilung unter Rinderklauen. Diplomarbeit, Munich, Germany. [In German]

Spielmann, C. 1990. Messung der Druckverteilung unter Rinderklauen. DVM Diss. Institute for Occupational Physiology, Technical University of Munich, Germany. [In German]

Sprecher, D. J., D. E. Hostetler, and J. B. Kaneene. 1997. A lameness scoring system that uses posture and gait to predict dairy cattle reproductive performance. Theriogenology 47:1179-1187. https:// doi.org/10.1016/S0093-691X(97)00098-8.

Sumiya, T., Y. Suzuki, T. Kasahara, and H. Ogata. 1998. Sensing stability and dynamic response of the F-Scan in-shoe sensing system: A technical note. J. Rehabil. Res. Dev. 35:192-200.

Telezhenko, E., C. Bergsten, M. Magnusson, M. Ventorp, and C. Nilsson. 2008. Effect of different flooring systems on weight and pressure distribution on claws of dairy cows. J. Dairy Sci. 91:18741884. https://doi.org/10.3168/jds.2007-0742.

Telezhenko, E., M. Magnusson, and C. Bergsten. 2017. Gait of dairy cows on floors with different slipperiness. J. Dairy Sci. 100:64946503. https://doi.org/10.3168/jds.2016-12208.

van der Tol, P. P. J., J. H. M. Metz, E. N. Noordhuizen-Stassen, W. Back, C. R. Braam, and W. A. Weijs. 2003. The vertical ground reaction force and the pressure distribution on the claws of dairy cows while walking on a flat substrate. J. Dairy Sci. 86:2875-2883. https://doi.org/10.3168/jds.S0022-0302(03)73884-3.

van der Tol, P. P. J., S. S. van der Beek, J. H. M. Metz, E. N. Noordhuizen-Stassen, W. Back, C. R. Braam, and W. A. Weijs. 2004. The effect of preventive trimming on weight bearing and force balance on the claws of dairy cattle. J. Dairy Sci. 87:1732-1738. https: //doi.org/10.3168/jds.S0022-0302(04)73327-5.

Vokey, F. J., C. L. Guard, H. N. Erb, and D. M. Galton. 2001. Effects of alley and stall surfaces on indices of claw and leg health in dairy cattle housed in a free-stall barn. J. Dairy Sci. 84:2686-2699. https://doi.org/10.3168/jds.S0022-0302(01)74723-6.

Walker, A. M., T. Pfau, A. Channon, and A. Wilson. 2010. Assessment of dairy cow locomotion in a commercial farm setting: The effects of walking speed on ground reaction forces and temporal and linear stride characteristics. Res. Vet. Sci. 88:179-187. https:/ /doi.org/10.1016/j.rvsc.2009.05.016.

Winckler, C., and G. Brill. 2004. Lameness prevalence and behavioural traits in cubicle housed dairy herds - A field study. Pages 160-161 in Proc. 13th Int. Symp. 5th Conf. Lameness in Ruminants, Maribor, Slovenia. B. Zemljic, ed. Ungula, Zemljic, and Company, Ormoz, Slovenia.

Zeiner, H., H. Schobesberger, M. Skalicky, and C. Stanek. 2007. Effect of different claw trimming methods on the pressure distribution under the bovine claw - an in vitro study. Berl. Munch. Tierarztl. Wochenschr. 120:165-172 